\title{
VALIDATION OF SIMBAT-PWR USING STANDARD CODE OF COBRA-EN ON REACTOR TRANSIENT CONDITION
}

\author{
Muhammad Darwis Isnaini, Muhammad Subekti \\ Center for Nuclear Reactor Technology and Safety, BATAN \\ Puspiptek Area Building no.80 Serpong, Tangerang Selatan, 15310 Indonesia \\ Email: darwis@batan.go.id \\ Diterima editor : 15 Februari 2016 \\ Direvisi editor : 4 Maret 2016 \\ Disetujui untuk dipublikasi : 24 Maret 2016
}

\begin{abstract}
VALIDATION OF SIMBAT-PWR USING STANDARD CODE OF COBRA-EN ON REACTOR TRANSIENT CONDITION. The validation of Pressurized Water Reactor typed Nuclear Power Plant simulator developed by BATAN (SIMBAT-PWR) using standard code of COBRA-EN on reactor transient condition has been done. The development of SIMBAT-PWR has accomplished several neutronics and thermal-hydraulic calculation modules. Therefore, the validation of the simulator is needed, especially in transient reactor operation condition. The research purpose is for characterizing the thermal-hydraulic parameters of PWR1000 core, which is able to be applied or as a comparison in developing the SIMBATPWR. The validation involves the calculation of the thermal-hydraulic parameters using COBRA-EN code. Furthermore, the calculation schemes are based on COBRA-EN with fixed material properties and dynamic properties that are calculated by MATPRO sub routine (COBRA-EN+MATPRO) for reactor condition of startup, power rise and power fluctuation from nominal to over power. The comparison of the temperature distribution at nominal 100\% power shows that the fuel centerline temperature calculated by SIMBAT-PWR has $8.76 \%$ higher than COBRA-EN and $7.70 \%$ lower than COBRA-EN+MATPRO. In general, SIMBATPWR calculation results on fuel temperature distribution are mostly between COBRA-EN and COBRAEN+MATPRO results. The deviations of the fuel centerline, fuel surface, inner and outer cladding as well as coolant bulk temperature in the SIMBAT-PWR and the COBRA-EN calculation, are due to the difference of the gap between heat transfer coefficient and the cladding thermal conductivity.
\end{abstract}

Keywords: transient, thermal-hydraulics, PWR, simulator, COBRA-EN, MATPRO.

\begin{abstract}
ABSTRAK
VALIDASI SIMBAT-PWR MENGGUNAKAN KODE STANDAR COBRA-EN DALAM KONDISI REAKTOR TRANSIEN. Telah dilakukan validasi Simulator Pembangkit Listrik Tenaga Nuklir tipe Pressurized Water Reactor yang dikembangkan oleh BATAN (SIMBAT-PWR) menggunakan kode standar COBRA-EN dalam kondisi reaktor transien. Pengembangan SIMBAT-PWR telah menyelesaikan beberapa modul perhitungan neutronik dan termohidraulika. Oleh karena itu, validasi simulator dibutuhkan, khususnya dalam kondisi operasi reaktor transien. Tujuan penelitian ini adalah untuk melakukan karakterisasi parameter termohidraulika teras PWR1000, agar dapat diaplikasikan atau sebagai pembanding dalam pengembangan simulator SIMBAT-PWR. Validasi memasukkan perhitungan parameter termohidraulika menggunakan kode COBRA-EN. Selanjutnya, skema perhitungan berbasis COBRA-EN dengan properti material tetap dan dinamis yang dihitung menggunakan subrutin MATPRO (COBRAEN+MATPRO) untuk kondisi reaktor startup, kenaikan daya dan fluktuasi daya dari daya nominal ke daya lebih. Perbandingan distribusi temperatur pada daya nominal 100\% menunjukkan bahwa temperatur tengah bahan bakar hasil perhitungan SIMBAT-PWR memiliki hasil lebih tinggi $8.76 \%$ dari pada hasil COBRA-EN dan lebih rendah $7.70 \%$ dari pada COBRA-EN+MATPRO. Pada umumnya, hasil perhitungan SIMBAT-PWR pada distribusi temperatur bahan bakar berada diantara hasil COBRA-EN dan COBRA-EN+MATPRO. Deviasi temperatur tengah bahan bakar, permukaan bahan bakar, kelongsong dalam, kelongsong luar dan pendingin bulk dalam perhitungan SIMBAT-PWR dan COBRA-EN adalah karena perbedaan nilai koefisien perpindahan panas gap dan konduktivitas termal kelongsong.
\end{abstract}

Kata kunci: transien, termohidraulika, PWR, simulator, COBRA-EN, MATPRO. 


\section{INTRODUCTION}

A simulator for pressurized water reactors (PWRs) called SIMBAT-PWR has been developed by BATAN for manifesting the human resource competence on nuclear reactor technology [1]. The simulator development is also for enhancing the understanding of NPP technologies especially the NPP's safety system to the government, society and student. Theoretically, the generated heat in a generic PWR core with power of $1000 \mathrm{MWe}$ (PWR1000) as simulator model is transferred by the primary coolant to generate steam in the steam generator. The generated steam will drive turbines for generating electricity. In the simulator development, the actual reactor operating parameters is designed to be displayed in real-time for showing the NPP operating condition, according to the power operations condition, such as coolant, fuel and cladding temperatures. Therefore, the user expects to study and monitor the behavior of NPP operation that could be fulfilled by the simulator during operation condition of startup, power rise or power transient from zero power to targeted reactor power level, and steady state at certain power level.

The research progress that supports NPP simulator development, has accomplished the module development for the determination of the radial distribution and fuel temperature [1] as well as thermal-hydraulic evaluation for AP1000 core and sub channel design [2]. In point of view of data completeness, PWR1000 design has been selected to be the model of the PWR simulator. Therefore, the thermal-hydraulic calculations for transient and steady state that required core material properties of meat, cladding, moderator and core grid, could be possibly done.

The simulator validation using the designed PWR1000 data and the standard code calculation is needed. However, the previous thermal-hydraulic analysis above has been carried out only at steady state. Consequently, more effort must be done at transient condition such as reactor's startup, rising to the nominal power, operating at nominal power and shut down conditions. Furthermore, there is more important effort that the simulator should be completed with the analysis for power perturbation to anticipate the power fluctuations (nominal power - over power nominal power) that occurred by operation errors. Therefore, the NPP simulator should be able to show all important values of thermal-hydraulic parameters as shown in the real reactor screen in a control room and as much as possible to have accurate parameters. This paper presents a validation of SIMBAT-PWR using standard code of COBRA-EN on reactor transient condition of (i) startup and power rise to nominal $100 \%$ power, and (ii) fluctuation of the nominal power towards over power $118 \%$ and return to the nominal $100 \%$ power.

The research purpose is for characterizing the core thermal-hydraulic parameters of PWR1000 in order to validate a NPP simulator, which is SIMBAT-PWR. The characterization of core thermal-hydraulic parameters of PWR was conducted on the reactor condition of start-up, rising power to the nominal power, stable at nominal power, and in anticipating power rise to over power, using computer code of COBRA-EN and PWR1000 design as reference. The benefit of this research is for a comparative analysis that is applied in the core thermal-hydraulic parameter characterization of SIMBAT-PWR.

\section{THEORY}

\section{SIMBAT-PWR for Transient Simulation}

SIMBAT-PWR has been developed by BATAN to simulate the NPP with respond time of a second as real time control room. Therefore, the neutronics and thermal-hydraulics calculation have been simplified so that the calculation result could be shown in screen for every second without any more delay time. The heat generated in fuel is removed by light water so that the calculation of temperature distribution is started from bulk water, outer cladding, inner cladding, outer meat, and centerline meat [1]. The SIMBAT-PWR screen showed the temperature distribution in a rod fuel hot spot at $100 \%$ power (right bottom side) as shown in Fig. 1. 


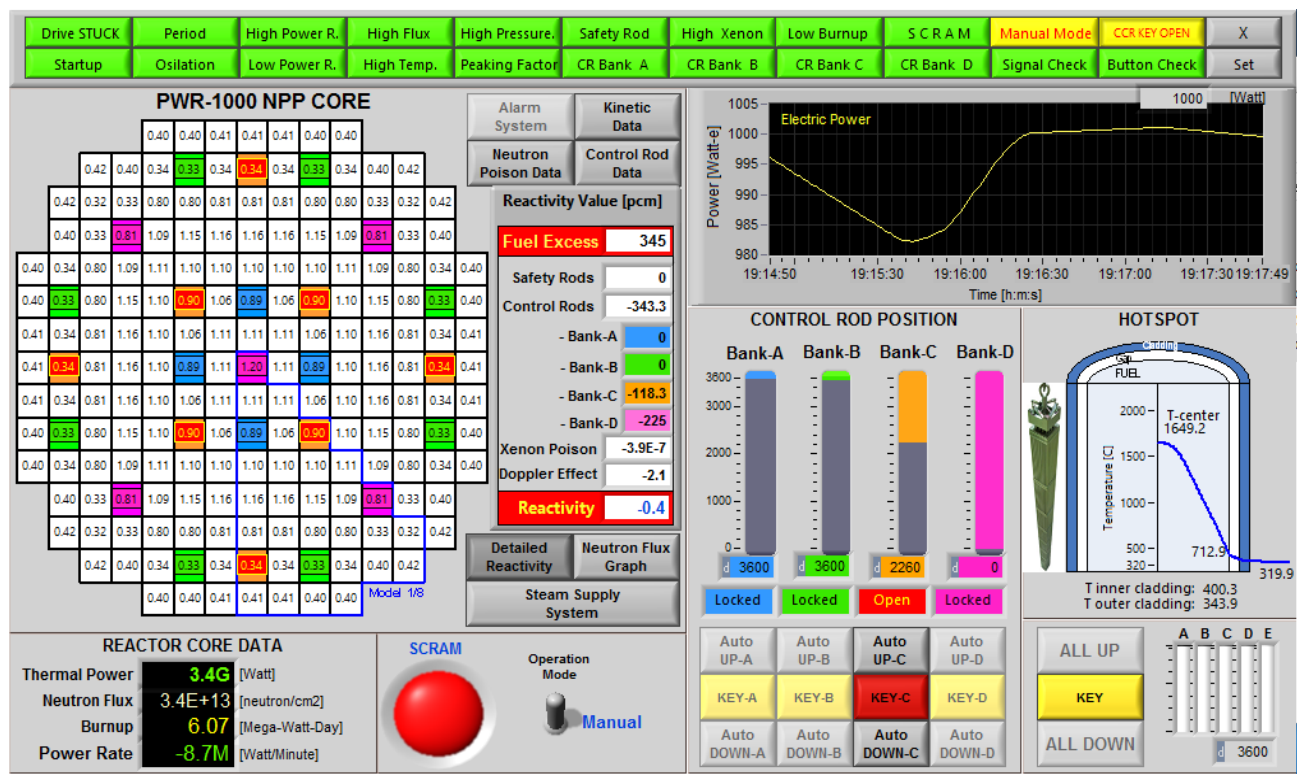

Figure 1. The SIMBAT-PWR screen showing the temperature distribution in a rod fuel hotspot at $100 \%$ power (right bottom side).

Table 1. The major difference between cold and hot startup condition [3].

\begin{tabular}{rcc}
\hline Parameters & Cold startup & Hot Startup \\
\hline Reactor coolant temperature $\left({ }^{\circ} \mathrm{C}\right)$ & 60 & 289 \\
Reactor coolant pressure $(\mathrm{MPa})$ & 2.8 & 15.5 \\
Pressurizer level $(\%)$ & 100 & 25 \\
Pressurizer temperatur $\left({ }^{\circ} \mathrm{C}\right)$ & 60 & 344 \\
\hline
\end{tabular}

The simulation of SIMBAT-PWR for startup and power rise condition refers to the operating procedure for PWR1000's Nuclear Steam Supply System (NSSS) [3]. The startup procedure below, applied to routine plant operation procedure. The procedure also depends on the plant condition that exist at the begining of operation. There were two types of startup, i.e., cold startup and hot startup. The major difference between the initial conditions of both startups was shown in Table 1. The cold startup is initiated to conduct reactor operation from shutdown condition in whicht the Reactor Cooling System (RCS) is depressurized. The hot startup is initiated to return to power operation following a shutdown condition, which does not require RCS depressurization, such as a restart following a turbine trip. The estimation of startup time required by PWR1000's NSSS for each startup condition is shown in Table 2.

Table 2. Estimation startup time in hours required by PWR1000's NSSS [3].

\begin{tabular}{lcc}
\multicolumn{1}{c}{ Operation } & Cold $^{*}$ & Hot $^{{ }^{1}}$ \\
\hline $\begin{array}{l}\text { 1. Raise primary system pressure to } 2.8 \mathrm{MPa} \text { and raise } \\
\text { pressure temperature to saturation at } 2.8 \mathrm{MPa} \text {. }\end{array}$ & 6.5 & - \\
2. Drain pressurizer to no-load operating level, maintaining \\
$\begin{array}{l}\text { system pressure at } 2.8 \mathrm{MPa} \text {. } \\
\text { 3. Withdraw control rods bank to criticality and rise output } \\
\text { to power range level. }\end{array}$ & 0.5 & - \\
$\begin{array}{l}\text { 4. Raise RCS to no-load conditions }\left(\mathrm{T}_{\text {avg }}=292^{\circ} \mathrm{C} \text { system }\right. \\
\text { pressure } 15.5 \mathrm{MPa})\end{array}$ & 3.5 & - \\
$\begin{array}{l}\text { 5. Raise the NSSS output to full power }(5 \text { percent per } \\
\text { minute). }\end{array}$ & 0.5 & 0.5 \\
\hline \multicolumn{1}{c}{ Total [hour] } & 13.0 & 1.0 \\
\hline
\end{tabular}

Cold - RCS temperature less than $60^{\circ} \mathrm{C}$, in "water solid" pressurizer.

${ }^{\circledR} \mathrm{Hot}$ - RCS temperature of $292^{\circ} \mathrm{C}, 15,5 \mathrm{MPa}$, no-load pressurizer level. 


\section{COBRA-EN Code}

The COBRA-EN code provides a capability for the analyses of the steady-state and transient condition of NPP of Light Water Reactor (LWR). This computer code uses the channel and sub channel analysis approach to determine the enthalpy and flow distribution in rod bundles for both steady state and transient conditions. The input data of this code are fuel rod geometry, thermal properties of fuel and cladding, the linear power, inlet mass flux for fuel channels and inlet coolant temperature, system exit pressure. The output are core pressure drop, distribution of enthalpy, coolant flow rate, fuel and cladding temperatures, heat flux, DNBR and heat transfer coefficient. This code has been used for several analyses such as thermal-hydraulic evaluation for AP1000 core and subchannel design [2], the influence of nozzle and spacer grid [4], radial and axial power fluctuation [5], VVER reactors [6-12].

There are two options for inputing the thermal properties of fuel and cladding in COBRA-EN input data. First option is by using fix values of thermal conductivities and specific heat of fuel and cladding. Second option is by using thermal conductivities and specific heat of fuel and cladding as a temperature functions (the value changed based on temperature reference) that will be calculated by MATPRO sub routine [13]. The sub routine of MATPRO uses several equations for calculating thermal conductivities and specific heat of fuel and cladding as a temperature functions, so that MATPRO has been used in analysis in VVER [12] and LWR [14-15].

The specific heat capacity in MATPRO is modelled empirically as functions of four parameters, i.e. temperature, composition, molten fraction and oxygen to metal ratio. The equation for specific heat of solid $\mathrm{UO}_{2}$ is shown in Equation (1) [13].

where:

$$
C_{p}=\frac{K_{1} \theta^{2} \exp (\theta / T)}{T^{2}[\exp (\theta / T)-1]^{2}}+K_{2} T+\frac{K_{3} E_{D}}{R T^{2}} \exp \left(-E_{D} / R T\right)
$$

$C_{p}:$ specific heat capacity of $\mathrm{UO}_{2}(\mathrm{~J} / \mathrm{kgK})$

$T:$ temperature $(\mathrm{K})$

$K_{1}:$ constant $=296.7(\mathrm{~J} / \mathrm{kg} \mathrm{K})$

$K_{2}: \quad$ constant $=2.43 \times 10^{-2}\left(\mathrm{~J} / \mathrm{kg} \mathrm{K}^{-2}\right)$

$K_{3}:$ constant $=8.745 \times 10^{7}(\mathrm{~J} / \mathrm{kg})$

$R \quad: \quad$ universal gas constant $=8.3143(\mathrm{~J} / \mathrm{molK})$

$\Theta \quad: \quad$ the Einstein temperature $=535.285(\mathrm{~K})$

$E_{D}:$ activation energy for Frenkel $\operatorname{defect}(\mathrm{J} / \mathrm{mol})$

It should be noted that the constants $K_{l}, K_{2}, K_{3}, \theta$ and $E_{D}$ determined for Equation (1) were only valid at fuel temperature above $300 \mathrm{~K}$. The standard error of the specific heat capacity equation of $\mathrm{UO}_{2}$ was $\pm 3 \mathrm{~J} / \mathrm{kgK}[16]$. The corelation of thermal conductivity of uncracked $\mathrm{UO}_{2}$ fuel in MATPRO was shown in Equation (2) [13].

$$
\begin{aligned}
& k=\left(\frac{D}{1+\left(6.5-0.00469 T^{\prime}\right)(1-D)}\right)\left(\frac{C_{V}}{\left(A+B T^{\prime \prime}\right)\left(1+3 e_{t h}\right)}\right) \cdots \cdots . . \\
& \ldots \ldots .+5.2997 \times 10^{-3} T[\exp (-13358 / T)]\left\{1+0.169[(13358 / T)+2]^{2}\right\}
\end{aligned}
$$

where:

$$
\begin{aligned}
k: & \text { thermal conductivity of } \mathrm{UO}_{2}(\mathrm{~W} / \mathrm{mK}) \\
D: & \text { fraction of theoretical density }(\cdot) \\
C_{V}: & \text { phonon contribution to the specific heat at constant volume }(\mathrm{J} / \mathrm{kgK}) \\
e_{t h}: & \text { linear strain caused by thermal expansion when temperature was upper that } 300 \mathrm{~K}(\cdot) \\
T: & \text { fuel temperature }(\mathrm{K}) \\
T^{\prime}: & \text { porosity correction } \\
& T^{\prime}=6.50-\mathrm{T}\left(4.69 \times 10^{-3}\right) \text { for temperature }<1364 \mathrm{~K}, \\
& T^{\prime}=-1 \text { for temperature }>1834 \mathrm{~K}, \text { and } \\
& T^{\prime} \text { was found by interpolation, for temperature in the range } 1364 \text { to } 1834 \mathrm{~K} \\
T^{\prime \prime}: \quad & \text { fuel temperature, if } \mathrm{T}<1800 \mathrm{~K},
\end{aligned}
$$


$T^{\prime \prime}=2050 \mathrm{~K}$ for fuel temperature $>2300 \mathrm{~K}$, and

$T$ " was found by interpolation, for temperature in the range 1800 to $2300 \mathrm{~K}$

$A$ : a factor proportional to the point defect contribution to the phonon mean free path $(\mathrm{ms} / \mathrm{kgK})$. The equation factor is $0.339+12.6 \times$ absolute value $(2.0-\mathrm{O} / \mathrm{M}$ ratio)

$B$ : a factor proportional to the phonon-phonon scattering contribution to the phonon mean free path $(\mathrm{ms} / \mathrm{kgK})$. The equation factor is $0.06867 \times(1+0.6238 \times$ plutonium content of fuel)

The data base of specific heat capacity of Zircaloy-4 in MATPRO was shown in Table 3.

Table 3. Data base of specific heat capacity of Zircaloy-4 [13].

\begin{tabular}{ccc}
\hline $\begin{array}{c}\text { Temperature } \\
(\mathrm{K})\end{array}$ & $\begin{array}{c}\text { Specifik heat capacity } \\
(\mathrm{J} / \mathrm{kgK})\end{array}$ & $\begin{array}{c}\text { Error standar MATPRO } \\
(\mathrm{J} / \mathrm{kgK})\end{array}$ \\
\hline 300 & 281 & 1.1 \\
400 & 302 & 1.1 \\
640 & 331 & 1.1 \\
1090 & 375 & 2.8 \\
\hline
\end{tabular}

The corelation of thermal conductivity of Zircaloy in MATPRO, that is used for temperature is less than $2098 \mathrm{~K}$, was shown in Equation (3). The standard error of the thermal conductivity for Zircaloy in equation (3) is $1.01 \mathrm{~W} / \mathrm{mK}$ [13].

$$
k=7.51+2.09 \times 10^{-2} T-1.45 \times 10^{-5} T^{2}+7.67 \times 10^{-9} T^{3}
$$

where:

$k:$ thermal conductivity of Zircaloy $(\mathrm{W} / \mathrm{mK})$

$T$ : temperature of Zircaloy (K)

\section{METHODOLOGY}

The validation of SIMBAT-PWR Simulator was done by the result comparison of the SIMBAT-PWR calculation to a standard code of COBRA-EN. The COBRA-EN calculation for PWR1000 were done by using several steps as explained below:

1. Utilize two calculation schemes based on COBRA-EN code:

1.a. First calculation utilizes COBRA-EN. The thermal-hydraulic analysis was done by using input data of fixed thermal properties of fuel and cladding, respectively (see Table 4),

1.b. Second calculation utilizes COBRA-EN+MATPRO for thermal property calculation as a temperature function, respectively (see Table 4).

2. Calculate both schemes by using of COBRA-EN code, and analyze the thermalhydraulic parameters for the condition below:

2.a. Startup and power rise to nominal $100 \%$ power, simulate hot startup at zero power and continues to power rise to nominal $100 \%$ power.

2.b. Anticipated operation of power fluctuation, simulates reactor power rise from nominal $100 \%$ power to $118 \%$ over power and return to the nominal power.

3. Compare and analysis the output of SIMBAT-PWR to the output COBRA-EN and the output of COBRA-EN+MATPRO.

The thermal properties of $\mathrm{UO}_{2}$ fuel and Zircaloy-4 cladding that are utilized in validation of SIMBATPWR and COBRA-EN code are shown in Table 4. 
Table 4. Thermal properties of $\mathrm{UO}_{2}$ fuel and cladding used in validation of SIMBAT-PWR Simulator.

\begin{tabular}{|c|c|c|c|c|}
\hline Thermal Properties & Unit & SIMBAT-PWR & COBRA-EN & $\begin{array}{l}\text { COBRA-EN } \\
+ \text { MATPRO }\end{array}$ \\
\hline \multicolumn{5}{|l|}{ Thermal conductivity of $\mathrm{UO}_{2}$ fuel } \\
\hline - Low Power & $\mathrm{W} / \mathrm{m}^{\circ} \mathrm{C}$ & 2.0 & 3.6 & equation \\
\hline - High Power & $\mathrm{W} / \mathrm{m}^{\circ} \mathrm{C}$ & 3.6 & 3.6 & equation \\
\hline $\begin{array}{l}\text { Thermal conductivity of Zircaloy- } 4 \\
\text { cladding }\end{array}$ & $\mathrm{W} / \mathrm{m}^{\circ} \mathrm{C}$ & 13.0 & 13.0 & equation \\
\hline \multicolumn{5}{|l|}{ Heat transfer coeficient } \\
\hline - Helium in fuel gap & $\mathrm{W} / \mathrm{m}^{2 \circ} \mathrm{C}$ & $5000-11000$ & 9982 & 9982 \\
\hline - Water Coolant & $\mathrm{W} / \mathrm{m}^{2 \circ} \mathrm{C}$ & 36000 & output & output \\
\hline
\end{tabular}

The calculation using COBRA-EN used PWR1000 core data that consists of 193 fuel assemblies, $3.66 \mathrm{~m}$ active length, with power generation of $3411 \mathrm{MWt}$ and core coolant flow-rate of $60.10 \times 10^{6} \mathrm{~kg} / \mathrm{h}$. The fuel rod length between center to center is $1.26 \mathrm{~cm}$, outer diameter is $0.95 \mathrm{~cm}$, cladding thickness is $0.0572 \mathrm{~cm}$ and fuel pellet diameter is $0.819 \mathrm{~cm}$ [1]. The operation limit for fuel centerline temperature shall be lower than $2800^{\circ} \mathrm{C}$ for prevention of center-line melt [16], the oxide fuel average temperature shall be lower than $1400^{\circ} \mathrm{C}$ for steady and nominal power [16], the Minimum Departure from Nucleate Boiling Ratio (MDNBR) shall be greater than 2.17 [16] for nominal power and 1.3 for design transient as well as over power [16]. COBRA-EN code used time step as shown in Table 5 for startup and Table 6 for power rise and power fluctuation.

Table 5. Time steps for startup and power rise.

\begin{tabular}{cc}
\hline Time $(\mathrm{s})$ & Power $(\%)$ \\
\hline 0 & 0 \\
2245 & 1 \\
2417 & 5 \\
2492 & 10 \\
2578 & 20 \\
2654 & 30 \\
2841 & 40 \\
3093 & 50 \\
3352 & 60 \\
3618 & 70 \\
3876 & 80 \\
4169 & 90 \\
4436 & 100 \\
4540 & 100 \\
\hline
\end{tabular}

Table 6. Time step for power fluctuation.

\begin{tabular}{cc}
\hline Time $(\mathrm{s})$ & Power $(\%)$ \\
\hline 0 & 100 \\
1000 & 100 \\
2000 & 118 \\
2200 & 118 \\
2800 & 100 \\
3000 & 100 \\
\hline
\end{tabular}

\section{RESULT AND ANALYSIS}

\section{Startup and Power Rise Condition}

Table 7 shows the comparison of the SIMBAT-PWR calculation results at nominal 100\% power to a standard code of COBRA-EN. The fuel centerline temperature is $1649.0^{\circ} \mathrm{C}$ for SIMBAT-PWR, $1504.55^{\circ} \mathrm{C}$ for COBRA-EN and $1775.95{ }^{\circ} \mathrm{C}$ for COBRA-EN+MATPRO. The SIMBAT-PWR result is between COBRA-EN with deviation of $-8.76 \%$ and COBRA-EN+MATPRO with deviation of $7.70 \%$. However, Fig. 2 shows the comparison of temperature increase in fuel centerline due to reactor power increase. If the reactor power less than $80 \%$, the fuel centerline temperature in SIMBAT-PWR becomes greater than either COBRA-EN or COBRA-EN+MATPRO, due to less of fuel thermal conductivity utilization effects on greater fuel temperature. In case of COBRA-EN+MATPRO calculation, the thermal conductivity is greater than or equal to $3.6 \mathrm{~W} / \mathrm{m}^{\circ} \mathrm{C}$ that is calculated by equation (1) and (2). In contrary, if the reactor power is greater than $80 \%$, the dynamic material properties calculated by MATPRO sub routine will decrease conductivity to be lower than fix 
conductivity in SIMBAT-PWR. Therefore, the fuel temperature in COBRA-EN+MATPRO will increase and exceed the SIMBAT-PWR calculation results as shown in Fig. 2.

Figure 3 shows temperature distribution in a rod fuel at nominal power of $100 \%$. As it can be seen in Fig. 3, SIMBAT-PWR calculation result is mostly between COBRA-EN and COBRAEN+MATPRO results. The deviation of the fuel centerline temperature in the SIMBAT-PWR and the COBRA-EN, is due to the value difference of the gap heat transfer coefficient and the cladding thermal conductivity. Smaller thermal conductivity of the SIMBAT-PWR causes the temperature difference of outer and inner cladding calculated by SIMBAT-PWR to be higher than COBRA-EN. On the other hand, the peak fuel centerline temperature of the COBRA-EN+MATPRO was higher than the one of the SIMBAT-PWR. It was caused by the value of thermal conductivity of COBRA-EN+MATPRO due to temperature function. Thermal conductivity as temperature function means that because the peak fuel centerline temperature was higher than the fuel surface temperature so that thermal conductivity in the centerline was smaller than the one on the edge or heat transfer in fuel center was worse than the heat transfer in the edge, so that the peak fuel center line temperature of COBRAEN+MATPRO was higher than the one of SIMBAT-PWR.

Table 7. The comparison of three calculation results of SIMBAT-PWR [1], COBRA-EN and COBRAEN+MATPRO at nominal power of $100 \%$.

\begin{tabular}{rcccccc}
\hline \hline $\begin{array}{c}\text { Temperature } \\
\text { Parameter }\left({ }^{\circ} \mathrm{C}\right)\end{array}$ & Design & SIMBAT-PWR & COBRA-EN & Deviation & $\begin{array}{c}\text { COBRA-EN } \\
\text { +MATPRO }\end{array}$ & Deviation \\
\hline Fuel centerline & - & 1649.0 & 1504.55 & $-8.76 \%$ & 1775.95 & $7.70 \%$ \\
Fuel average & - & - & 1062.39 & - & 1138.15 & - \\
Fuel surface & - & - & 585.25 & - & 569.05 & - \\
Inner clad & - & 400.3 & 416.65 & $4.08 \%$ & 400.45 & $0.04 \%$ \\
Outer clad & - & 344.0 & 348.75 & $1.38 \%$ & 348.75 & $1.38 \%$ \\
Outlet coolant & 325.0 & 320.9 & 321.14 & $0.07 \%$ & 321.14 & $0.07 \%$ \\
\hline
\end{tabular}

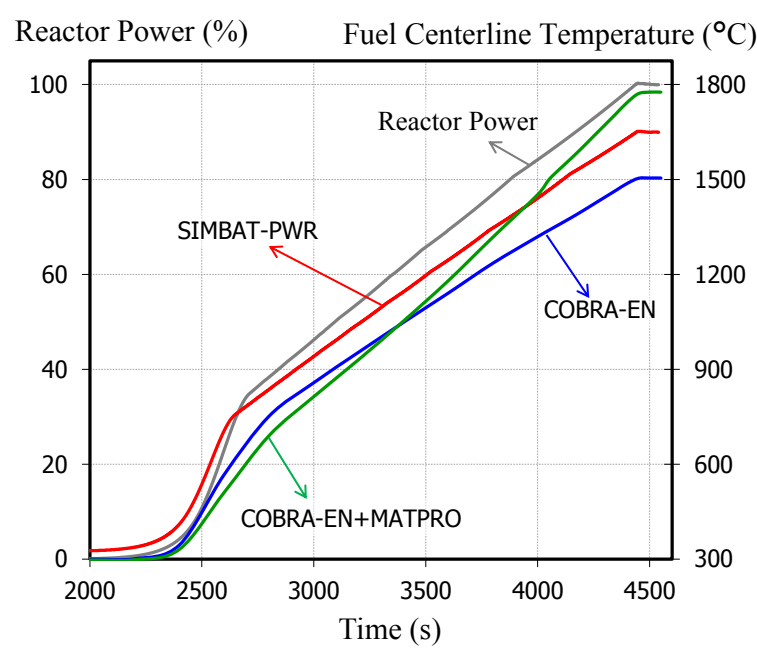

Figure 2. The comparison of temperature increase in fuel centerline due to reactor power increase.

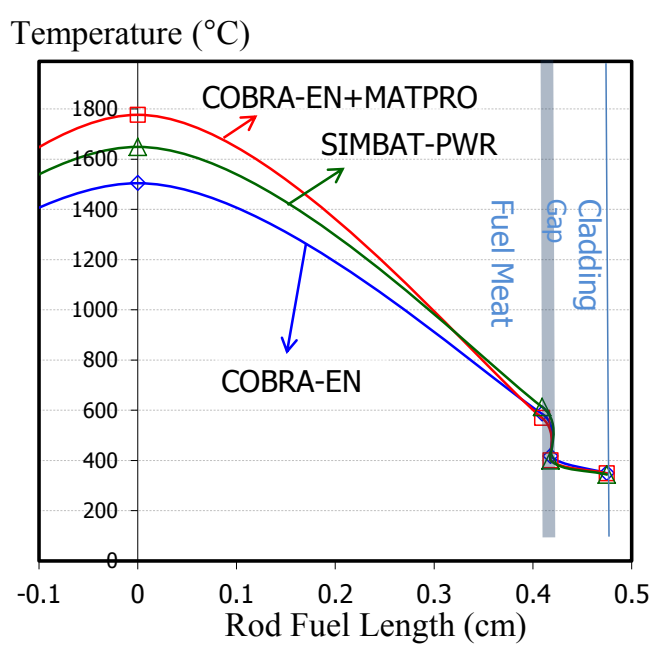

Figure 3. Temperature distribution in a rod fuel at nominal $100 \%$ power.

Furthermore, the temperature comparison between COBRA-EN+MATPRO (thermal equation) and COBRA-EN (fixed thermal properties) shows larger deviation in Fig. 2 and Fig. 3. Although COBRA-EN+MATPRO code utilizes thermal property equation, the resulted fuel centerline temperature is higher than COBRA-EN code. However, the resulted fuel surface and inner cladding temperatures are lower with insignificant deviation as shown in Figure 3. The fuel meat surface and 
inner cladding temperatures of COBRA-EN+MATPRO are $569.05{ }^{\circ} \mathrm{C}$ and $400.45{ }^{\circ} \mathrm{C}$, respectively, lower $2.78 \%$ and $3.89 \%$ than the COBRA-EN values of $585.25^{\circ} \mathrm{C}$ and $416.65^{\circ} \mathrm{C}$, respectively.

\section{Power Fluctuation}

Validation for $118 \%$ overpower fluctuations has been done. The comparison of calculation results between SIMBAT-PWR, COBRA-EN, and COBRA-EN+MATPRO at over power $118 \%$ are shown in Table 8. The calculation result deviation for fuel centerline temperature between SIMBATPWR and COBRA-EN is $-1.45 \%$ in which the temperature is $1735.95{ }^{\circ} \mathrm{C}$ for SIMBAT-PWR and $1713.85{ }^{\circ} \mathrm{C}$ for COBRA-EN. Furthermore, the advanced deviation increases to $20.25 \%$ in comparison with COBRA-EN+MATPRO. The comparison result on power fluctuation agrees with previous comparison on startup and power rise. The SIMBAT-PWR calculation results for fuel centerline temperature between COBRA-EN and COBRA-EN+MATPRO are shown in Table 8.

Table 8. The comparison of calculation results between SIMBAT-PWR, COBRA-EN and COBRAEN+MATPRO at over power $118 \%$.

\begin{tabular}{rrrcrc}
\hline $\begin{array}{c}\text { Temperature } \\
\text { Parameter }\left({ }^{\circ} \mathrm{C}\right)\end{array}$ & SIMBAT-PWR & COBRA-EN & Deviation & $\begin{array}{c}\text { COBRA-EN } \\
\text { + MATPRO }\end{array}$ & Deviation \\
\hline Peak fuel centerline & 1739.15 & 1713.85 & $-1.45 \%$ & 2091.25 & $20.25 \%$ \\
Fuel average & - & 1192.05 & - & 1324.75 & - \\
Fuel surface & 739.24 & 629.05 & $14.91 \%$ & 609.65 & $-17.53 \%$ \\
Inner clad & 405.41 & 430.05 & $6.08 \%$ & 410.65 & $1.29 \%$ \\
Outer clad & 345.17 & 349.75 & $1.33 \%$ & 349.75 & $1.33 \%$ \\
Outlet coolant & 324.52 & 326.02 & $0.46 \%$ & 326.02 & $0.46 \%$ \\
\hline
\end{tabular}

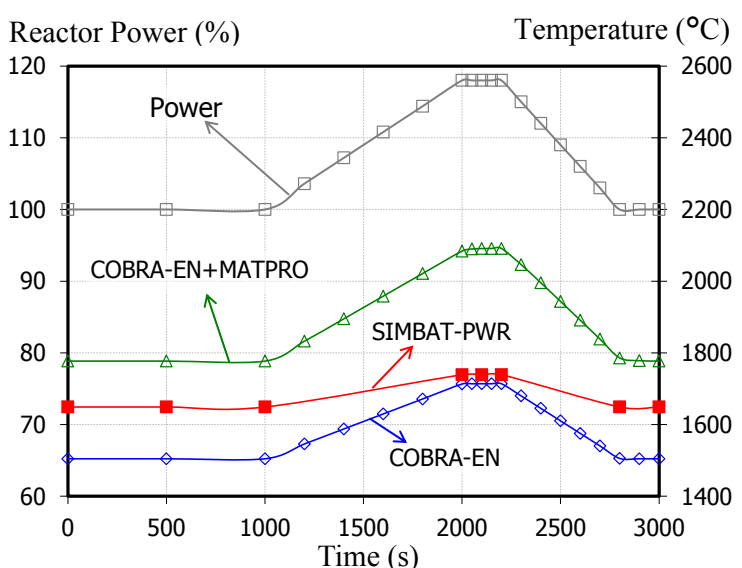

Fig. 4. More detail comparison for fuel centerline temperature using SIMBAT-PWR, COBRA-EN and COBRA-EN+MATPRO at over power $118 \%$.

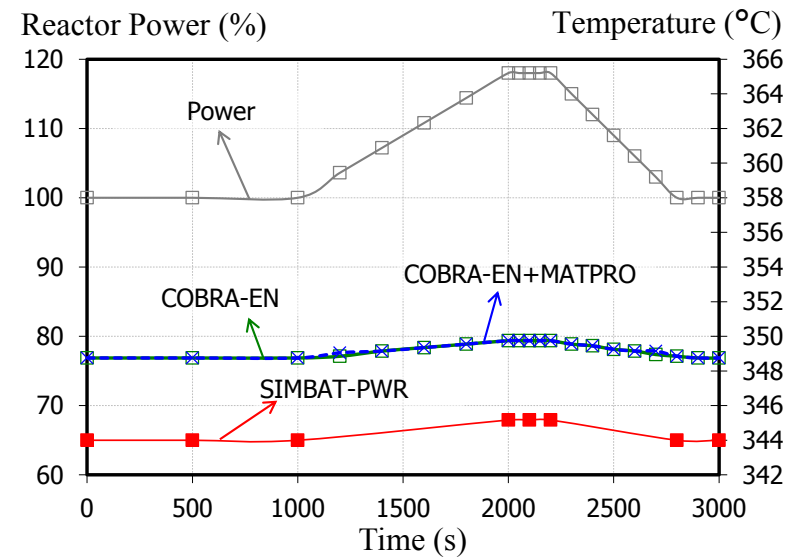

Fig. 5. More detail comparison for outer cladding temperature using SIMBAT-PWR, COBRA-EN and COBRA-EN+MATPRO at over power $118 \%$.

More detail comparison using SIMBAT-PWR, COBRA-EN and COBRA-EN+MATPRO at over power $118 \%$ are shown in Fig. 4 for fuel centerline temperature and Fig. 5 for outer cladding temperature. To respond to the increasing power to $118 \%$, the fuel centerline temperature in SIMBATPWR increases $5.47 \%$ from $1649.0{ }^{\circ} \mathrm{C}$ to $1739.15^{\circ} \mathrm{C}$. In the same fluctuation simulation, COBRA-EN code has larger temperature increase of $13.91 \%$ in fuel centerline from $1504.55{ }^{\circ} \mathrm{C}$ to $1713.85{ }^{\circ} \mathrm{C}$. By using material property equation, COBRA-EN+MATPRO code has largest temperature increase of $17.64 \%$ for fuel centerline from $1775.95^{\circ} \mathrm{C}$ to $2091.25^{\circ} \mathrm{C}$. Although the fuel centerline temperature of SIMBAT-PWR is in the range between COBRA-EN and COBRA-EN+MATPRO, however the 
temperature increase of SIMBAT-PWR is preferred between COBRA-EN and COBRAEN+MATPRO or at least close to $13.91 \%$ temperature increase (should be about $1878{ }^{\circ} \mathrm{C}$ ).

Figure 4 shows another detail effect of power fluctuation of $118 \%$ over power. The outer clad temperature of SIMBAT-PWR increase $0.34 \%$ from $344.0{ }^{\circ} \mathrm{C}$ to $345.17{ }^{\circ} \mathrm{C}$, in which COBRA-EN and COBRA-EN+MATPRO have the similar cladding temperature increase of $0.29 \%$. The cladding temperature increase comparison shows that SIMBAT-PWR has acceptable calculation result. In the core thermal-hydraulics calculation, the SIMBAT-PWR and COBRA-EN code have similar method for calculating temperature distribution in bulk coolant, outer cladding, inner cladding, fuel meat wall, and fuel centerline.

\section{CONCLUSIONS}

The validation of SIMBAT-PWR has been done by the utilization of COBRA-EN and COBRAEN+MATPRO for transient operation condition of startup, power rise and fluctuation power from nominal $100 \%$ power to overpower $118 \%$. The comparison of the temperature distribution at nominal $100 \%$ power shows that the fuel centerline temperature calculated by SIMBAT-PWR has $8.76 \%$ higher than COBRA-EN calculation result. However, the utilization of MATPRO subroutine based on dynamic property calculation shows $7.70 \%$ higher than SIMBAT-PWR. Furthermore, the similar comparison at over power $118 \%$ shows that the fuel centerline temperature calculated by SIMBATPWR has $1.45 \%$ higher than COBRA-EN and $20.25 \%$ lower than COBRA-EN+MATPRO. In general, SIMBAT-PWR calculation results on fuel temperature distribution are mostly between COBRA-EN and COBRA-EN+MATPRO results. In the case of power fluctuation until over power $118 \%$, the SIMBAT-PWR show similar area calculation results, between COBRA-EN and COBRAEN+MATPRO results. The deviations of the fuel centerline, fuel surface, inner and outer cladding as well as coolant bulk temperature in the SIMBAT-PWR and the COBRA-EN, are due to the value difference of the gap heat transfer coefficient and the cladding thermal conductivity.

\section{REFERENCES}

1. Subekti M., Darwis Isnaini M., Endiah P.H. The determination of radial fuel temperature in PWR-NPP simulator on steady state. Proceeding of Basic Research on Nuclear Science and Technology, PTAPB-BATAN, Yogyakarta;2012.p.76-81.

2. Darwis Isnaini M., Dibyo S., Suroso, Geni RS., Endiah P.H., Subekti M. Evaluation of core and subchannel thermal-hydraulics design parameter of AP1000 nuclear power plants on steady state condition. Journal of Reactor Technology of Tri Dasa Mega 2012; 14(1):14-28.

3. Anonymous The westinghouse pressurized water reactor nuclear power plant, Westinghouse Electric Corporation Water Reactor Divisions, Chapter 16: Plant Operation, (1984). p. 207218.

4. Darwis Isnaini M. The influence of nozzle and spacer grid against thermal-hydraulics parameters of AP1000 reactor fuel assemblies. Journal of Reactor Technology of Tri Dasa Mega 2013; 15(3): 159-170.

5. Darwis Isnaini M., Widodo S., Subekti M. The thermal-hydraulics analysis on radial and axial power fluctuation for AP1000 reactor. Journal of Reactor Technology of Tri Dasa Mega 2015; 17(2): 79-86.

6. Aghaie M., Zolfaghari A., Minuchehr M., Norouzi A. Enhancement of COBRA-EN capability for VVER reactor calculations. Annals of Nuclear Energy 2012; 46: 236-243.

7. Rahmani Y., Pazirandeh A., Ghofrani M.B., Sadighi M. Calculation of the deterministic optimum loading pattern of the BUSHEHR VVER-1000 reactor using the weighting factor method. Annals of Nuclear Energy 2012; 49: 170-181. 
8. Zarifi E., Jahanfarnia G., Veysi F. Thermal-hydraulics modeling of nanofluids as the coolant in VVER-1000 reactor core by the porous media approach. Annals of Nuclear Energy 2013; 51: 203-212.

9. Zarifi E., Jahanfarnia G., Veysi F. Subchannel analysis of nanofluids application to VVER1000 reactor. Chemical Engineering Research and Design 2013; 91: 625-632.

10. Faghihi F., Mirvakili S.M. Shut-down margin study for the next generation VVER-1000 reactor including $13 \times 13$ hexagonal annular assemblies. Annals of Nuclear Energy 2011; 38: 2533-2540.

11. Kalkhoran O.N., Minuchehr A., Shirani A.S., Rahgoshay M. Full scope thermal-neutronic analysis of LOFA in a VVER-1000 reactor core by coupling PARCS v2.7 and COBRA-EN. Progress in Nuclear Energy 2014; 74: 193-200.

12. Rahgoshay M., Tilehnoee M.H. Optimizing a gap conductance model applicable to VVER1000 thermal-hydraulic model. Annals of Nuclear Energy 2012; 50: 263-267.

13. Siefken 1.J., Coryell E.E., Harvego E.A., Hohorst J.K. MATPRO - A library of materials properties for light water reactor accident analysis, NUREG/CR-6150, Vol. 4, Rev.2. (2001). p. $2.1-2.16$ and $4.1-4.25$.

14. Terrani K.A., Wang D., Ott L.J., Montgomery R.O. The effect of thermal conductivity on the behavior of LWR cores during Loss-of-Coolant Accidents. Journal of Nuclear Materials 2014; 448: 512-519.

15. Ott L.J., Robb K.R., Wang D. Preliminary assessment of accident-tolerant fuels on LWR performance during normal operation and under DB and BDB accident condition. Journal of Nuclear Materials 2014; 448: 520-533.

16. Shuffler C., Trant J., Malen J., Todreas N. Thermal hydraulic analysis for grid supported pressurized water reactor cores. Nuclear Engineering and Design 2009; 239: 1442-1460. 